Research.

\title{
IMPACT OF ANTECEDENTS OF TAX ADMINISTRATION MODERNIZATION AND AWARENESS ON INDIVIDUAL TAXPAYER'S COMPLIANCE IN JAKARTA - INDONESIA
}

\author{
Riris Rotua Sitorus \\ Department of Accounting, University of 17 Agustus 1945, Jakarta, Indonesia \\ riris.sito@gmail.com (R. R. Sitorus)
}

\begin{abstract}
Received: October 24, 2018; Accepted: November 21, 2018; Published: December 31, 2018 To cite this article: Riris Rotua Sitorus. Impact of Antecedents of Tax Administration Modernization and Awareness on Individual Taxpayer's Compliance in Jakarta - Indonesia, The Accounting Journal of BINANIAGA, Vol. 03, No. 02, December 2018, pp. 55-66.
\end{abstract}

\begin{abstract}
This study provides empirical evidence on the effect of modernization of tax administration and awareness on compliance of individual taxpayers in North Jakarta. The Components of modernization of tax administration that being exogenous variables are e-registration, e-filing, e-payment, e-counseling, e-SPT, and e-invoicing. Awareness taxpayer variable is another exogenous variable. Tax compliance is an endogenous variable in this study. The respondents of this study were 65 individual taxpayers, freelancers and also workers as a tax consultant. Using the Smart PLS software, proved that e-registration, e-filing, e-payment, e-counseling, e-SPT, and einvoicing significantly influenced taxpayer's compliance. While awareness of the taxpayer does not have any influence on taxpayer's compliance.
\end{abstract}

Key words: Modernization of tax administration, Awareness, Compliance, Individual taxpayers

\section{INTRODUCTION}

In 2015, Indonesia has been succeeding to record the economic growth into 4, 7\% and the budget deficit within safe limits. This achievement becomes the foundation to face 2016. However, for state budget (APBN) of 2016, the government sets an ambitious budget target. The state revenues targeted to reach Rp. 1.822 trillion, of which about 75 $\%$ or Rp 1.360 trillion comes from tax revenues administered by the Directorate General of Taxation. It has increased almost $30 \%$ of realization in 2015. Therefore, it needs different and unusual effort in order to achieve the target. As applicable in OECD countries, around $50 \%$ of tax revenue derived from the individual taxpayers, so that they become the main focus of tax revenue. If the tax revenue focuses on an individual with a high economic level, the economic growth does not significantly affect the revenue and group consumption, so it has no effect to the tax revenue. It needs different and unusual effort in order to achieve the tax revenue target in 2016. However, principally, to collect the tax revenue is not only the job of the Directorate General of Taxes but also all the people in this country, start from President, parliament, Minister/Institutions, law enforcement, social organization, tax consultant, and citizen play an important role in realizing the independence of the state in the form of collecting the tax revenue optimally (Hidayat, 2016). Considering the information above, it is important to improve taxpayer compliance in order to achieve the target in 2016. It takes a synergy between qualified human resources, a good mechanism, and technology information in applying electronic system in the environment of directorate general of taxation.

Riris Rotua Sitorus. Impact of Antecedents of Tax Administration Modernization and Awareness on Individual Taxpayer's Compliance in Jakarta - Indonesia 
According to Fasmi and Misra (2012), the Directorate General of Taxation (DJP) has launched a change program or reformation of the tax administration briefly so-called modernization since 2002. The soul of this modernization program is the implementation of good governance, which is the application of the tax administration system that is transparent and accountable, by utilizing information systems that are reliable and latest technology. The strategy adopted is providing excellent service and at the same time giving intensive supervision to the taxpayers. Rahayu and Lingga (2009) state the tax administration reform program embodied in the application of modern tax administration system which has a special characteristic such as organizational structure designed by the function, no longer according to the sections based on the type of tax, the improvement of services for every taxpayer through the establishment account representative and compliant center to accommodate objections taxpayer. At the end of the tax administration modernization, it will bring taxpayers in a more secure position and consciously perform their tax obligations with ease. Awareness taxpayer will lead them to be obedient when at the same time supported with electronic system.

If the combination among external factor, modernization administration of taxation of the taxpayer, and taxpayer's awareness are well synergized, it will lead the taxpayer being obedient. Several previous literatures and studies proved that the modernization of tax administration (Kirani 2010 and Fasmi \& Misra, 2012) and the taxpayer awareness (Arum, 2012 and Muliari \& Setiawan, 2011) has been linked with the taxpayer compliance. Based on those facts and the previous achievement studies, it will be researched again about the influence of modernization of tax administration (e registration, e-filing, e-payment, e-counseling, e-SPT, and e-invoicing) and the awareness of taxpayers towards taxpayer compliance. This research entitled "The Effect of Modernization of the Tax Administration and the Awareness on Compliance of Individual Taxpayers in North Jakarta".

\section{LITERATURE REVIEW AND HYPOTHESIS}

\section{Theory of Planned Behavior}

Theory of Planned Behavior is a grand theory used in this study, and it also used to explain the factors that can affect taxpayer compliance. It explains that the behavior posed by the individuals appearing for their intention to behave (Ajzen, 2005). Behavior tax compliance or never started from the intention of individual taxpayer. The taxpayers will behave obedient because they intend to be obedient. As well as those who disobey the tax happened because they do not intend to be obedient.

According to the terminology, compliance is obedient, submissive, and follows the order/regulation, and so on. The obedient taxpayers are the taxpayers who obey the tax obligations in accordance with the applicable constitution. It is in line with Rahman (2009) that the tax compliance is a situation where the taxpayers fulfill all tax liability and implement their right of taxation. There are two types of obedience, such as: 1) Formal obedience. It is a justice in which the taxpayer formally fulfills tax obligations in accordance with the tax laws. 2) Material obedient. It is based on the content of tax laws. It may include formal compliance. The taxpayers who fulfill the taxpayer compliance are the taxpayers that fill the Notification Later (SPT) honestly, completely and correctly accordance with the rules and submit it to the tax office before the deadline. Based on Rahman, et al (2008), to increase taxpayer's compliance in fulfilling their obligation, it needs to be done by the tax compliance as common compliance and awareness of obligation taxation, which reflected in the situation, where the taxpayers: (1) understanding or attempting to understand all the provisions of the tax legislation; (2) filling out the tax form completely and clearly; (3) calculating the amount of tax payable correctly; and (4) paying tax owed on time.

Theory of Planned Behavior is related to the modernization variable and tax administration. Modernization administration of taxation is designed to make the

Riris Rotua Sitorus. Impact of Antecedents of Tax Administration Modernization and Awareness on Individual Taxpayer's Compliance in Jakarta - Indonesia 
taxpayers easily to implement the taxation liabilities. Taxpayers are placed in a position that is easier to process tax reporting. The principal of modernization of the tax administration is expected to invite the intention of the taxpayers to make their tax obligations obediently. Planned behavior of taxpayers to comply shall be supported by the modernization of tax administration. Theory of Planned Behavior is also related to the awareness of the taxpayers. When taxpayers are well aware of their rights and obligations as a good taxpayer, the taxpayers should be behaving obedient to all aspects of taxation they will do.

\section{The Effect of Modernization of the Tax Administration toward Taxpayer Compliance}

Tax administration is prosecuted to become dynamic as an effort to increase the effective implementation of tax policy. Criteria visibility of administration is demanded that the new tax system minimizes the administrative costs and covers the compliance costs as well as making tax administration as a part of tax policy (Sofyan, 2005). According to Slemrod and Blumenthal (1996), based on their study in the United States, the amount of compliance cost to be incurred by the taxpayer is relatively high compared with tax income by the Internal Revenue Service (IRS). They also state the amount of compliance costs can be minimized through process simplification of tax despite these problems sometimes do not become a concern in setting tax policy. Wijayanti, et al., (2004) found that modernization is expected to enhance the accountability of the effect of the tax authorities on tax compliance. Some characteristics of modernization of tax administration are all activities of administration carried out through an administration system based on the latest technology, all taxpayers are required to pay through the on-line office, all taxpayers are required to report the tax obligations by using computer media (e-SPT), and monitoring the compliance intensively. The Director of taxation as a government organization which is authorized to manage taxation is fully aware that without improvisation in information technology field, the evolving dynamics in society, especially the business dynamics cannot be anticipated (Prawirodidirdjo, 2007). The most important thing the maximal use of information technology will support transparency and openness program, where the possibility of corruption, collusion and nepotism (KKN) including abuse of power can be minimized. The support from the information technology can accelerate the process and inspection services. With the development of databases in an online network, it allows the speed access to get the information and to fill the Notification Later (SPT), and an online tax payment which makes the administration process becomes much simpler. According Fasmi and Misra (2012), modern tax administration system also follow the progress of technology e-systems service such as e-registration, e-filing, e-payment, e-counseling, e-SPT, and e-invoicing which are expected to increase more effective control mechanism that is supported by the application of the Code employees Directorate General of Taxes that governs the behavior of employees in implementing the tasks and the implementation of good governance. Based on Sony and Rahayu (2010), the indicators in the modernization of the tax administration system are as follows: (1) the administrative system, (2) the effectiveness of supervision, (3) professional human resources. The use of e-system is focused on the use of e-filing, because it is the one which gives easier effect than the previous manual way. The study done by Rahayu and Lingga (2009) entitled "The Influence of Tax Administration System Modernization of the Taxpayer Compliance" gives the finding that the effect of the administration of the tax system modernization is not significant on tax compliance. In contrast to the study done by Kirani (2010) entitled "Taxpayer Receipt Behavior Analysis of the use of e -filing (Empirical Studies in the city of Semarang)" showed the evidence that the taxpayer's behavior acceptance has significant effect on e-filing. Based on the analysis and review the results of the previous studies, it was determined the research hypothesis as follows:

$\mathrm{H}_{1}$ : There is a significant influence of the e-registration on tax compliance.

$\mathrm{H}_{2}$ : There is a significant influence of the e-filing on tax compliance.

$\mathrm{H}_{3}$ : There is a significant influence of e-payment on tax compliance.

$\mathrm{H}_{4}$ : There is a significant influence of the e-counseling on tax compliance.

Riris Rotua Sitorus. Impact of Antecedents of Tax Administration Modernization and Awareness on Individual Taxpayer's Compliance in Jakarta - Indonesia 
$\mathrm{H}_{5}$ : There is a significant influence of the e-spt on tax compliance.

$\mathrm{H}_{6}$ : There is a significant influence of the e-invoicings on tax compliance.

\section{The Effect of Taxpayers Awareness toward Taxpayers Compliance}

The taxpayer's awareness is a condition where the taxpayers know, understand, and implement the tax obligation correctly and voluntarily. The higher the level of taxpayer's awareness, the better the taxpayer's understanding tax obligation and it can lead them to the tax obedient (Muliari and Setiawan, 2011). The Lower awareness of taxpayers often becomes one of the reasons that the taxes are not paid by them. The higher the level of taxpayer's awareness, the better the taxpayer's understanding tax obligation and it can lead them to the tax obedient, the taxpayer's awareness on the tax function as slate funding is needed to improve taxpayer compliance (Arum, 2012). Based on the analysis and review the results of the previous studies, it was determined that the research hypothesis is as follows:

$\mathrm{H}_{7}$ : There is a significant influence of the taxpayer's awareness on tax compliance.

\section{RESEARCH METHOD}

This study is a fundamental study which is aimed to improve the knowledge and the existing theories to confirm the previous studies (Sekaran, 2013). This study seeks to explain the influence between variables through testing the hypothesis (verification study) to test the correctness of the theory or previous studies. It made verification descriptive, before testing the hypothesis or testing the verification. This study is categorized as quasi experimental study. According to the approach, this study is quantitative study. It is based on the philosophy of positivism that sees the reality and phenomena can be classified, relatively fixed, concrete, observable, measurable, and the relationship is causal symptoms (Sugiyono, 2013).

This study is used 48 taxpayers from individual, freelance, and tax consultant in North Jakarta as the respondent. The respondents were determined using purposive sampling method, with the criteria that respondents self-reported their taxes, work and live in North Jakarta, and can be met when the survey was conducted. This study is used Structural Equation Modeling with Partial Least Square. Before testing the hypothesis, first tested the reliability of the data, which is testing the validity of confirmatory factor analysis method. Furthermore, the reliability test data is done by testing the composite reliability and cross loadings (Ghozali, 2006). Furthermore, testing the hypothesis was done by using output inner weight of partial least square. follows:

Definitions and measurement indicators for each variable used in this study are as

1. Modernization of the tax administration system is a development program in the taxation system, especially in the field of administration conducted by the agencies in order to maximize tax revenue in the country (Khasanah 2013). According Fasmi and Misra (2012), the modern tax administration system is realized based on esystems such as e -registration, e-filing, e-payment, e-counseling, e-SPT, and einvoicing. Each section has a success indicator like, administrative system, effectiveness of supervision, and professional resources.

2. Taxpayer's awareness is a condition where the taxpayers know, understand and implement the provisions of the tax correctly and voluntary. The higher the level of taxpayer's awareness, the better the taxpayer's understanding tax obligation and it can lead them to the tax obedient (Muliari and Setiawan, 2011). The taxpayer is said to have awareness of taxation if in accordance with the following matters: (1) determine their laws and tax regulations, (2) determine the function of the tax is for state financing, (3) understand that the tax obligations should be implemented in

Riris Rotua Sitorus. Impact of Antecedents of Tax Administration Modernization and Awareness on Individual Taxpayer's Compliance in Jakarta - Indonesia 
accordance with applicable regulations, (4) understand the functions of taxes for state financing, (5) calculate, pay, report taxes voluntarily, (6) calculate , pay , report taxes properly (Asri, 2009).

3. Tax compliance is a devout attitude in fulfilling and implementing tax obligations in accordance with the applicable provisions of the tax laws (Rahman, 2009). Tax compliance requires the taxpayers to fulfill all tax obligations and implement their right of taxation. Tax compliance is reflected in situations where the taxpayer: (1) Understanding or attempting to understand all the provisions of the tax legislation; (2) Filling out tax forms with complete and clear; (3) Calculating the amount of tax payable correctly, and (4) Paying taxes owed on time.

\section{THE RESULT OF THE STUDY}

This study used 48 respondents as a sample. In analyzing the data, this study used structural equation modeling approach seas partial square. The steps of data processing using Smart PLS consists of several stages such as: test the validity of using the outer loadings, goodness of fit test using the composite reliability and cross loadings. Then, this study used path coefficients to test the hypothesis. The results of each steps which are implemented, as follows:

\section{Testing the Validity by using Outer Loadings}

Outer loadings (measurement model) or convergent validity used to test undimensionality of each construct. Chin (1998), the value of the indicator loading factor greater than or equal to 0.5 can be said to be valid. Consider the following picture:

Figure 1

Validity with Outer Loadings

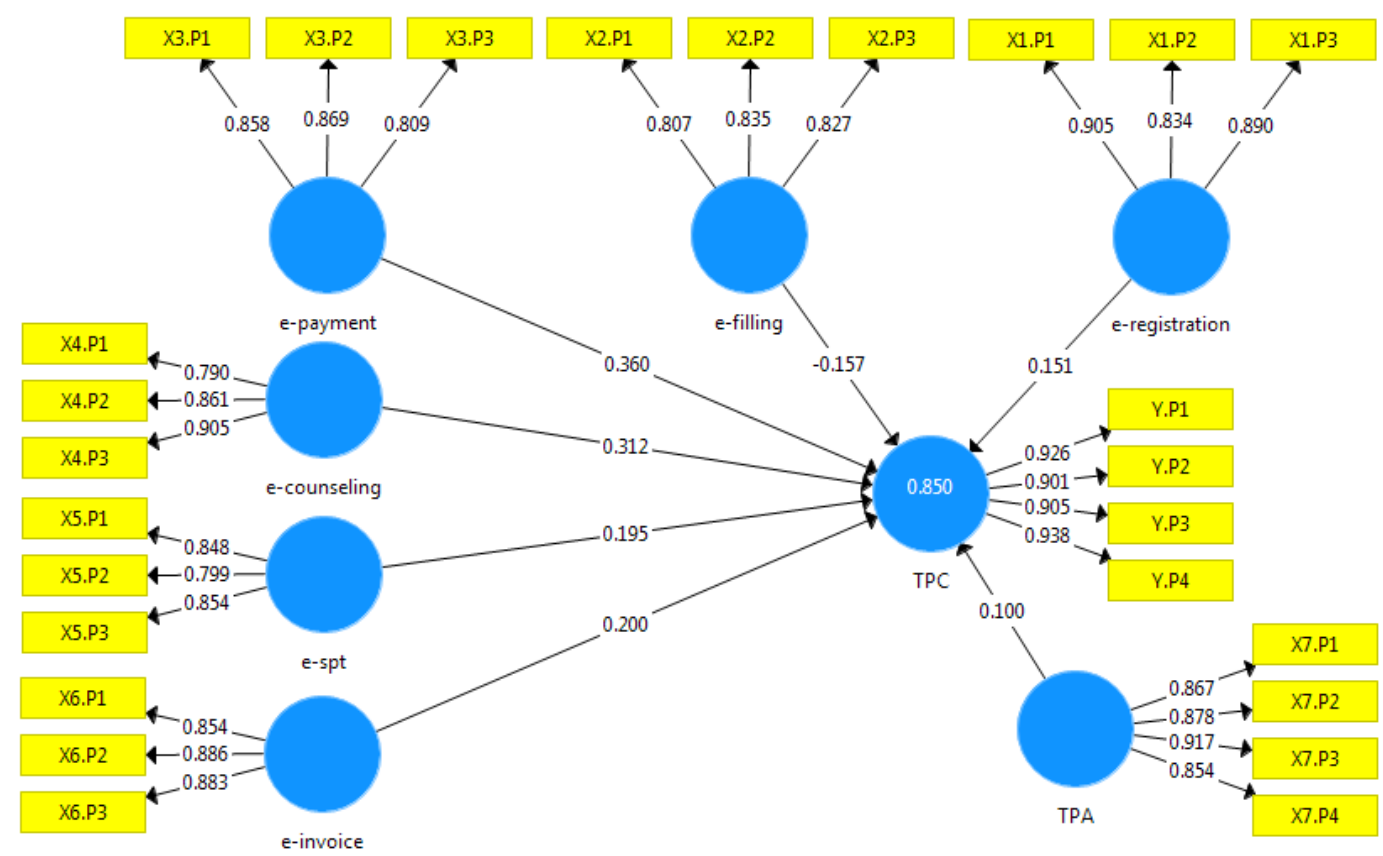

Source: Data Smart PLS, 2016

Based on the result above, it can be concluded that all indicators are valid because all outer loadings are $>0.5$

Riris Rotua Sitorus. Impact of Antecedents of Tax Administration Modernization and Awareness on Individual Taxpayer's Compliance in Jakarta - Indonesia 


\section{Composite Reliability}

Chin W (1998) states that "The unidimensionality of the block of variables may be assessed by using the composite reliability (should be $>0.7$ )". The reliability test of data is done by composite reliability with the following results:

\section{Diagram 1}

Results of Composite Reliability

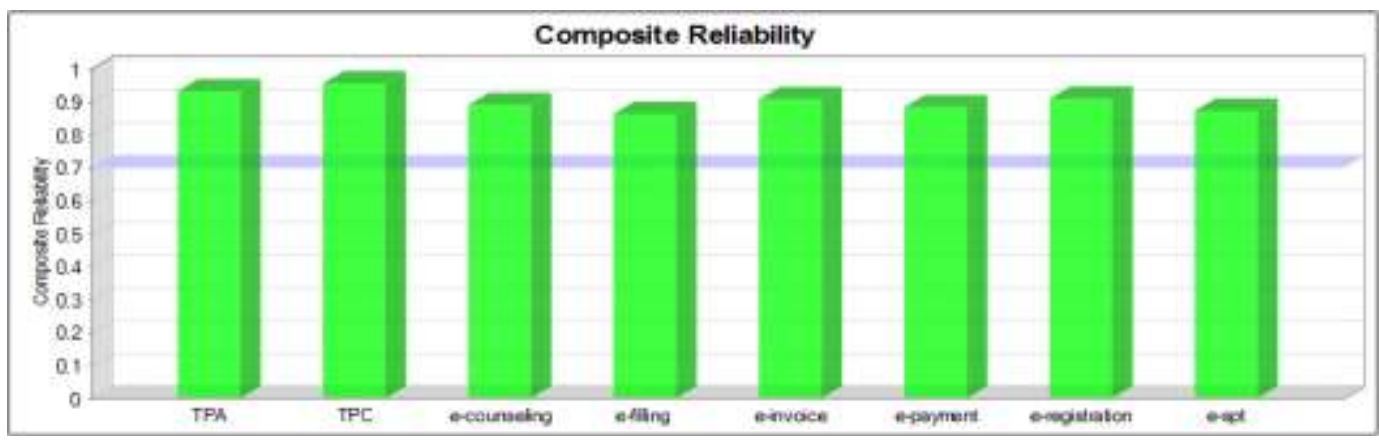

Source: Data Smart PLS, 2016

It can be seen from the result of composite reliability above, the overall test results are above 0.70 . Thus, it can be concluded that the variable data modernization of tax administration (e-registration, e-filing, e-payment, e-counseling, e-SPT, e-invoicing) and variable awareness of the taxpayer is reliable, and can be used for testing the hypothesis.

\section{Cronbach Alpha}

Cronbach alpha is a consistency test of respondents' answers that prove the respondent focus on answering the questionnaire. Respondents' answers would be reliable when the Cronbach alpha values $>0.7$ (Chin, W., 1998). The result of Cronbach alpha below shows that all the results are reliable.

\section{Diagram 2}

Results of Cronbach Alpha

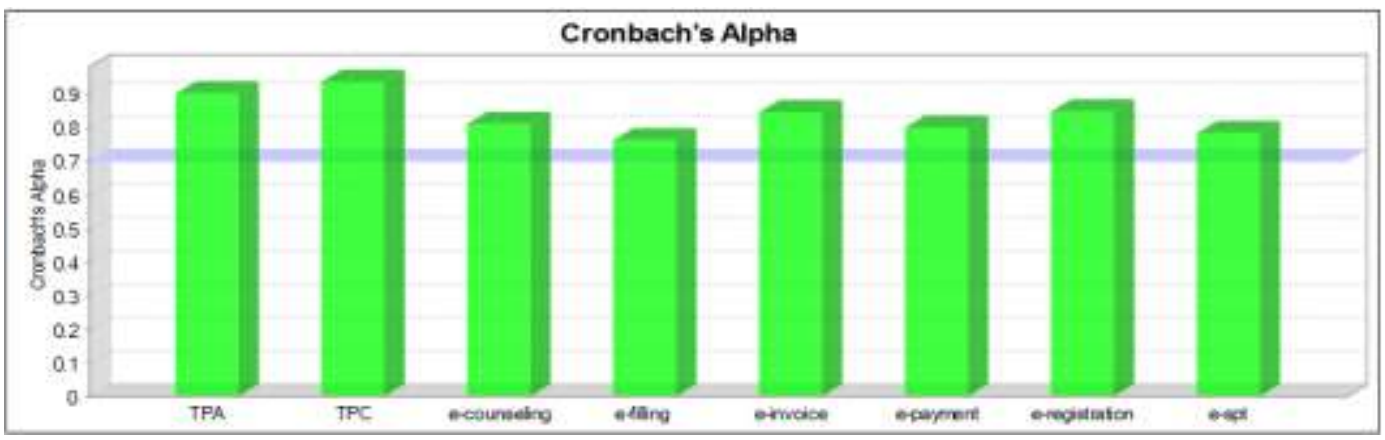

Source: Data Smart PLS, 2016

\section{Cross Loadings}

Cross Loadings is part of the goodness of fit which is intended to test the quality of the data, that the correlation value of each variable with the indicator must be greater than the variable correlation with indicators of other variables. It can be seen from following results:

Riris Rotua Sitorus. Impact of Antecedents of Tax Administration Modernization and Awareness on Individual Taxpayer's Compliance in Jakarta - Indonesia 
Table 1

Results of Cross Loadings

\begin{tabular}{|c|c|c|c|c|c|c|c|c|}
\hline Item & $\begin{array}{l}\text { TPC } \\
(Y)\end{array}$ & $\begin{array}{l}\text { TPA } \\
\text { (X7) }\end{array}$ & $\begin{array}{c}\text { e-Counseling } \\
\text { (X4) }\end{array}$ & $\begin{array}{l}\text { e-invoicing } \\
\text { (X6) }\end{array}$ & $\begin{array}{l}\text { e-filing } \\
\text { (X2) }\end{array}$ & $\begin{array}{l}\text { e-Payment } \\
\text { (X3) }\end{array}$ & $\begin{array}{c}\text { e-Registration } \\
\text { (X1) }\end{array}$ & $\begin{array}{l}\text { e-Spt } \\
\text { (X5) }\end{array}$ \\
\hline X1.P1 & 0.375 & 0.300 & 0.209 & 0.250 & 0.393 & 0.266 & 0.905 & 0.380 \\
\hline X1.P2 & 0.363 & 0.218 & 0.231 & 0.075 & 0.454 & 0.249 & 0.834 & 0.417 \\
\hline X1.P3 & 0.319 & 0.225 & 0.201 & 0.120 & 0.332 & 0.228 & 0.890 & 0.326 \\
\hline X2.P1 & 0.399 & 0.501 & 0.389 & 0.383 & 0.807 & 0.417 & 0.309 & 0.534 \\
\hline X2.P2 & 0.481 & 0.464 & 0.437 & 0.310 & 0.835 & 0.565 & 0.376 & 0.557 \\
\hline X2.P3 & 0.411 & 0.465 & 0.399 & 0.244 & 0.827 & 0.442 & 0.428 & 0.384 \\
\hline X3.P1 & 0.705 & 0.418 & 0.542 & 0.547 & 0.552 & 0.858 & 0.245 & 0.637 \\
\hline X3.P2 & 0.688 & 0.516 & 0.636 & 0.528 & 0.497 & 0.869 & 0.243 & 0.503 \\
\hline X3.P3 & 0.653 & 0.458 & 0.420 & 0.458 & 0.425 & 0.809 & 0.231 & 0.452 \\
\hline X4.P1 & 0.609 & 0.609 & 0.790 & 0.309 & 0.330 & 0.370 & 0.152 & 0.537 \\
\hline X4.P2 & 0.633 & 0.518 & 0.861 & 0.297 & 0.520 & 0.571 & 0.263 & 0.471 \\
\hline X4.P3 & 0.720 & 0.624 & 0.905 & 0.425 & 0.425 & 0.658 & 0.209 & 0.585 \\
\hline X5.P1 & 0.538 & 0.443 & 0.432 & 0.452 & 0.538 & 0.426 & 0.307 & 0.848 \\
\hline X5.P2 & 0.722 & 0.489 & 0.631 & 0.449 & 0.389 & 0.642 & 0.375 & 0.799 \\
\hline X5.P3 & 0.572 & 0.554 & 0.457 & 0.366 & 0.601 & 0.465 & 0.381 & 0.854 \\
\hline X6.P1 & 0.543 & 0.361 & 0.307 & 0.854 & 0.373 & 0.504 & 0.189 & 0.393 \\
\hline X6.P2 & 0.517 & 0.314 & 0.321 & 0.886 & 0.236 & 0.488 & 0.087 & 0.399 \\
\hline X6.P3 & 0.634 & 0.379 & 0.424 & 0.883 & 0.372 & 0.585 & 0.169 & 0.530 \\
\hline Y.P1 & 0.926 & 0.617 & 0.707 & 0.653 & 0.440 & 0.709 & 0.343 & 0.683 \\
\hline Y.P2 & 0.901 & 0.604 & 0.688 & 0.575 & 0.522 & 0.771 & 0.365 & 0.626 \\
\hline Y.P3 & 0.905 & 0.584 & 0.719 & 0.536 & 0.516 & 0.740 & 0.402 & 0.771 \\
\hline Y.P4 & 0.938 & 0.617 & 0.708 & 0.624 & 0.455 & 0.742 & 0.374 & 0.664 \\
\hline Z.P1 & 0.607 & 0.867 & 0.654 & 0.324 & 0.452 & 0.471 & 0.220 & 0.531 \\
\hline Z.P2 & 0.532 & 0.878 & 0.603 & 0.311 & 0.463 & 0.446 & 0.308 & 0.431 \\
\hline Z.P3 & 0.588 & 0.917 & 0.563 & 0.321 & 0.563 & 0.546 & 0.247 & 0.517 \\
\hline Z.P4 & 0.586 & 0.854 & 0.584 & 0.461 & 0.550 & 0.459 & 0.232 & 0.612 \\
\hline
\end{tabular}

Source: Data Smart PLS, 2016

Based on the table above, it can be seen that the correlation between the variables with each indicator is always greater than the cross correlation loading. It can be concluded that the data of research was fit and well used for hypothesis testing process.

\section{The Result of Testing the Hypothesis}

In this study, the result of testing the hypothesis use path coefficients which are processed with PLS. Below are the output results of testing the hypothesis:

Riris Rotua Sitorus. Impact of Antecedents of Tax Administration Modernization and Awareness on Individual Taxpayer's Compliance in Jakarta - Indonesia 
Table 2

Result for Path Coefficient

\begin{tabular}{|l|r|r|r|r|r|}
\hline & Original Sample (O) & Sample Mean (M) & Standard Deviation (STDEV) & T Statistics (|O/STDEV|) & P Values \\
\hline TPA -> TPC & 0.100 & 0.095 & 0.082 & 1.218 & 0.224 \\
\hline e-counseling -> TPC & 0.312 & 0.318 & 0.096 & 3.232 & 0.001 \\
\hline e-filling -> TPC & -0.157 & -0.160 & 0.083 & 1.905 & 0.057 \\
\hline e-invoice -> TPC & 0.200 & 0.208 & 0.085 & $2.356 \mid$ & 0.019 \\
\hline e-payment -> TPC & 0.360 & 0.362 & 0.098 & 3.683 & 0.000 \\
\hline e-registration -> TPC & 0.151 & 0.156 & 0.052 & 2.880 & 0.004 \\
\hline e-spt -> TPC & 0.195 & 0.184 & 0.071 & 2.740 \\
\hline
\end{tabular}

Source: Data Smart PLS, 2016

Meanwhile, for picture of research model and the hypothesis testing results can be seen from the image below:

Picture 2

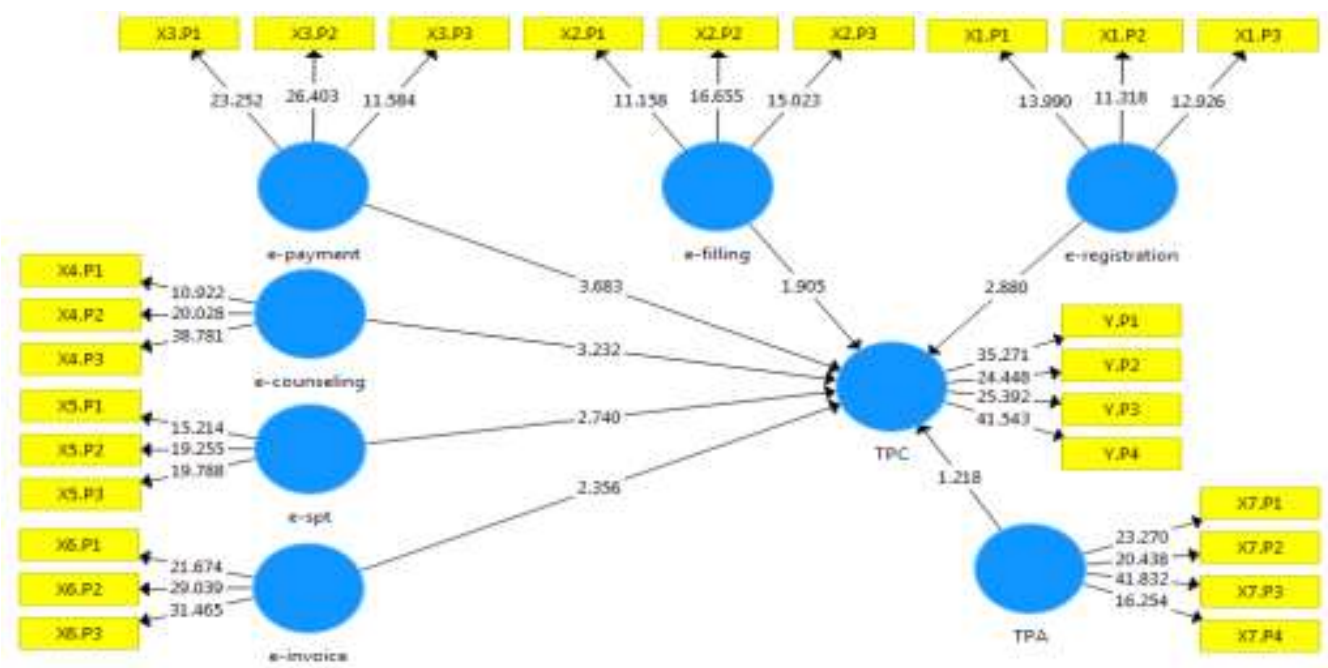

Source: Data Smart PLS, 2016

Based on the output of testing the hypothesis above, the answer of each hypothesis of the variable study of modernization of tax administration (e-registration, efiling, e-payment, e-counseling, e-SPT, e-invoicing) and variable taxpayer's awareness, that are proposed in this study are as follows:

1. Modernization of tax administration with e-registration has a significant effect to the taxpayer's compliance. It was proved by the value gained from $T$ statistics was $2.880>1.96$ (hypothesis is accepted) and the coefficient was 0.151 .

2. Modernization of tax administration with e-filing did not have an effect to the taxpayer's compliance. It was proved by the value gained from the $T$ statistics was $1.905<1.96$ (hypothesis is rejected) and the coefficient was -0.157 .

3. Modernization of tax administration with e-payment has a significant effect to the taxpayer's compliance. It was proved by the value gained from the $T$ statistics was $3.683>1.96$ (hypothesis is accepted) and the coefficient was 0.360 .

4. Modernization of tax administration with e-counseling has a significant effect to the taxpayer's compliance. It was proved by the value gained from the $T$ statistics was $3.232>1.96$ (hypothesis is accepted) and the coefficient was 0.312 .

Riris Rotua Sitorus. Impact of Antecedents of Tax Administration Modernization and Awareness on Individual Taxpayer's Compliance in Jakarta - Indonesia 
5. Modernization of tax administration with e-SPT has an effect to the taxpayer's compliance. It was proved by the value gained from the T statistics was $2.740>1.96$ (hypothesis is accepted) and the coefficient was 0.195 .

6. Modernization of tax administration with e-invoicing has an effect to the taxpayer's compliance. It was proved by the value gained from the T statistics was $2.356>1.96$ (hypothesis is accepted) and the coefficient was 0.200 .

7. Taxpayer's awareness has no significant effect to the taxpayer's compliance. It was proved by the value gained from the $T$ statistics was $1.218<1.96$ (hypothesis is rejected) and the coefficient was 0.100 .

\section{Discussion}

Variable of taxpayer's awareness has no effect on the tax compliance. It means that it is not proven the relevance and influence in this study. It can also be said that the awareness of taxpayers is not yet fully achieved. But it could also be said that the awareness of paying taxes already exist, but have not been able to encourage tax compliance. Modernization strongly supports the process of tax compliance. It is influenced by the convenience provided by the modernization of tax administration. For the future, the improvement of tax compliance will support the budget and state budget (APBN). The model of APBN is currently depending on tax revenue, which means that our taxes are the foundation of national economic resilience.

\section{Determination Coefficient}

Determination coefficient (R-square) is the capability of independent variables (exogenous) to explain the dependent variables (endogenous). In this study, dependent variable is taxpayer's compliance variable. While, independent variable is modernization of tax administration variable (e-registration, e-filing, e-payment, e-counseling, e-SPT, einvocing) and taxpayer's awareness variable. The results can be seen as follows:

Table 3

The Result of R-Square

\begin{tabular}{|l|c|}
\hline & R Square \\
\hline $\begin{array}{l}\text { Taxpayer's compliance } \\
\text { (TPC) }\end{array}$ & 0.850 \\
\hline
\end{tabular}

Source: Data Smart PLS, 2016

The result shows that the ability of modernization of tax administration variables (eregistration, e-filing, e-payment, e-counseling, e-SPT, e-invoicing) and taxpayer's awareness variable in explaining the tax compliance is 0.850 or $85 \%$, which means that the chances of other variables in explaining the variable tax compliance is $15 \%$.

\section{CONCLUSION AND RECOMMENDATION}

The conclusion of this study is the answer to the formulation of the problem. The conclusion is modernization of tax administration variable (e-registration, e-payment, ecounseling, e-SPT, and e-invoicing) significantly effect taxpayer's compliance, except efiling, has no effect on taxpayer's compliance. Meanwhile, the taxpayer's awareness has no effect on tax compliance. The limitation of this study is only examined the individual taxpayers in North Jakarta, Indonesia. For further study, it is suggested to examine the individual taxpayers in greater numbers and in the wider region. For the taxpayers, the results of this study suggest that we must more obedient to the tax regulation. The model of APBN currently is depending on the tax revenue, which means that our tax is the basic foundation for national economic resilience.

Riris Rotua Sitorus. Impact of Antecedents of Tax Administration Modernization and Awareness on Individual Taxpayer's Compliance in Jakarta - Indonesia 


\section{REFERENCE}

Ajzen, I. (2005). Attitude, Personality, and Behavior (2nd ed.). Berkshire, UK: Open University Press-McGraw Hill Education.

Arum. (2012). Influence of Taxpayer Awareness, Service Tax Authorities, and Sanctions To Tax Compliance Personal Tax Payer who Conducting Business and Employment Free (studies at the Cilacap region). Scription. Diponegoro University. Semarang.

Asri, M., and Wuri. (2009). Influence of Service Quality, Cost of Tax Compliance and Taxpayer's Awareness on Corporate Taxpayer's Reporting Compliance that Registered in Tax Office Madya Denpasar. Sription. Economic Fakulty of Udayana University.

Chin, W.W. (1998). The Partial Least Squares Approach for Structural Equation Modeling. Modern Methods For Business Research (pp. 295-336). Mahwah, New Jersey: Lawrence Erlbaum Associates Publisher.

Fasmi, L., and Misra, F. (2012). Effect of Tax Administration System Modernization On Taxable Entrepreneur's Compliance Level at Padang Pratama Tax Office. Scription. Andalas University.

Ghozali, I. (2006). Structural Equation Modeling, Alternative Method by Partial Least Square (PLS). Semarang: Universitas Diponegoro.

Hidayat, A. (2016). Tax Revenue Outlook 2016. Retrieved from http://www.pajak.go.id/content/article.

Khasanah, S.N. (2014). The Effect of Tax Knowledge, Tax Administration System Modernization and Taxpayer's Awareness on Taxpayer's Compliance at the Regional Office of Directorate General of Taxation DI Yogyakarta. Scription. Yogyakarta State University. Yogyakarta.

Kirani, GG. 2010. Taxpayer Receipt Behavior Analysis on the Use of e-Filing (Empirical Studies on Semarang). Scription. Faculty of Economics, University of Diponegoro. Semarang.

Muliari, N.K., and Setiawan, P.E. (2011). Influence of Perception About Tax Sanctions and Taxpayer's Awareness on Taxpayer's Reporting Compliance in Primary Tax Office East Denpasar. Accounting and Business Science Journal, Vol.6 (1).

Prawirodirdjo, SA. (2007). Influence Analysis of Organizational Change and Cultural Organization on Employee Satisfaction and Performance of Taxation Directorate General. Institutional Repository. Diponegoro University.

Rahayu, S., and Lingga, I.S. (2009). Impact of Tax Administration System Modernization on Taxpayer's Compliance. Accounting Journal, Vol.1 (2), 119-138.

Rahman, A. (2009). The Relationships Modern Tax Administration System with Taxpayer's Compliance. Journal of Administrative Sciences, Vol.6 (1), 31-38.

Sekaran, U., and Bougie, R. (2013). Research Methods for Business: A Skill Building Approach (6th ed.). Wiley.

Slemrod, J.B., and Blumenthal, M. (1996). The Income Tax Compliance Cost of Big Business. Public Finance Quarterly, Vol. 24 (14), 411-438.

Riris Rotua Sitorus. Impact of Antecedents of Tax Administration Modernization and Awareness on Individual Taxpayer's Compliance in Jakarta - Indonesia 
Devano, S., and Rahayu, S.K. (2006). Taxation: Concepts, Theories and Issues. Jakarta: Kencana.

Sofyan, T.M. (2005). Effect of Implementation of Modern Tax Administration System on Taxpayer's Compliance at Tax Office in Regional Office of Directorate General of Taxes of Large Taxpayer. Scription. State College of Accountancy Degree. Jakarta.

Sugiyono. (2013). Quantitative Research Method. Bandung: Alfabeta.

Wijayanti, R., Kurniawati, H.D., and Febri, D. (2004). Towards Good Governance through the Modernization of Tax (e-SPT). Malang: STIE-MCE ABIS.

Riris Rotua Sitorus. Impact of Antecedents of Tax Administration Modernization and Awareness on Individual Taxpayer's Compliance in Jakarta - Indonesia 
The Accounting Journal of BINANIAGA Vol. 03, No. 02, December 2018

PISSN: $2527-4309$

EISSN: $2580-1481$

This page intentionally be emptied.

Riris Rotua Sitorus. Impact of Antecedents of Tax Administration Modernization and Awareness on Individual Taxpayer's Compliance in Jakarta - Indonesia 